\title{
EDITORIAL
}

\section{The role of plerixafor in optimizing peripheral blood stem cell mobilization for autologous stem cell transplantation}

\author{
Leukemia (2011) 25, 1-6; doi:10.1038/leu.2010.224
}

High-dose chemotherapy with or without radiation therapy is an effective treatment strategy for patients with non-Hodgkin's lymphoma (NHL), multiple myeloma (MM) and Hodgkin's lymphoma. The myelosuppressive or myeloablative effects of high-dose chemotherapy, however, require subsequent hematopoietic stem cell (HSC) transplantation to help restore bone marrow function. The preferred HSC source is from the patient's peripheral blood. ${ }^{1}$ This requires stem cell mobilization from the bone marrow into the bloodstream for collection. The classical HSC mobilization approach relies on granulocyte colonystimulating factor (G-CSF) either as a single agent or in conjunction with chemotherapy (chemomobilization). This is considered the standard of care for HSC mobilization despite evidence that mobilization fails in $5-40 \%$ of cases. ${ }^{2,3}$ Plerixafor is a novel CXCR4 chemokine-receptor antagonist for autologous HSC mobilization, which gained Food and Drug Administration (FDA) approval in 2008 and European Medicines Agency (EMEA) approval in 2009. This editorial will consider the benefits and limitations of G-CSF HSC mobilization and examine the potential role of plerixafor in daily clinical practice.

Irrespective of the mobilization regimen used, the success or failure of HSC mobilization is, in part, dictated by the target number of cells to be harvested. The generally accepted minimum $\mathrm{CD}_{3} 4^{+}$cell yield for transplant is $\geqslant 2 \times 10^{6}$ $\mathrm{CD}^{2}{ }^{+}{ }^{\text {cells }} / \mathrm{kg}^{4}$ although higher cell doses of $4-5 \times 10^{6}$ $\mathrm{CD} 4^{+}$cell/kg or greater are associated with faster neutrophil and platelet recovery, reduced hospitalizations, reduced blood transfusions and antibiotic treatment. ${ }^{5}$ Many transplant centers, therefore, define their target cell dose as an 'optimal' dose (usually $4-6 \times 10^{6} \mathrm{CD} 34^{+}$cells per $\mathrm{kg}$ of recipient body weight). Higher cell doses may be collected from patients with MM when tandem transplantation is considered. There are also acknowledged risk factors for suboptimal HSC mobilization. These include older age ( $>60$ years); progressive disease and heavy bone marrow involvement; previous chemotherapy and/ or radiotherapy; type of antineoplastic drug used (for example, fludarabine, melphalan, lenalidomide and so on); previously failed mobilization attempts; platelet counts of $\leqslant 100 \times 10^{9} / \mathrm{I}$ before apheresis; and neutropenic fever during mobilization. ${ }^{2,4-9}$ Risk factors, practical constraints, as well as the need to reduce tumor burden by disease-specific chemotherapy, affect the choice of mobilization method for each patient.

G-CSF (filgrastim and lenograstim)-mediated HSC mobilization is believed to involve the disruption of adhesion molecules such as vascular cell adhesion molecule-1, c-kit, CXCR4 and SDF-1 to release stem cells from bone marrow niches. ${ }^{10}$ The definitive mechanism is unclear; however, there is evidence that the sympathetic nervous system is also involved in regulating HSC attraction to bone marrow niches. ${ }^{11}$ As a single agent, G-CSF is used mostly at a dose of $10 \mu \mathrm{g} / \mathrm{kg}$ subcutaneously daily, initiated 4 days before the first apheresis session and continued until the last day of apheresis. Circulating CD $34^{+}$cells usually peak on days 5-6 after G-CSF initiation. Stem cells are usually collected in a median of 2-5 apheresis sessions. ${ }^{3}$ G-CSF has a relatively mild toxicity profile, although rarely have severe adverse events such as splenic rupture, lung injury and vascular events been reported. ${ }^{12}$ A significant number of patients are unable to mobilize sufficient cells for auto-HSC transplantation with G-CSF alone. In a retrospective study of $1834 \mathrm{NHL}$, Hodgkin's lymphoma and MM patients, 26.8, 26.4 and $6.6 \%$, respectively, were unable to collect the required $\geqslant 2 \times 10^{6}$ $\mathrm{CD} 4^{+}$cells $/ \mathrm{kg} .^{4}$

Chemotherapy used in intensive myelosuppressive treatments mobilizes HSCs to the peripheral blood as a result of compensatory neutrophil production following chemotherapyinduced aplasia. Chemotherapy used in conjunction with G-CSF is more effective in mobilizing HSCs than either chemotherapy or G-CSF alone. ${ }^{13}$ However, one study reports that the percentage of patients achieving a minimum $2 \times 10^{6} \mathrm{CD} 34^{+}$ cells $/ \mathrm{kg}$ is similar to those using G-CSF alone; failure rates are similar, and remobilization attempts with G-CSF with or without chemotherapy are equally likely to fail. ${ }^{4}$ Nevertheless, G-CSF with chemotherapy may achieve more successful mobilizations in patients heavily pretreated with chemotherapy, ${ }^{14}$ and cyclophosphamide, or etoposide, in combination with G-CSF has been used to rescue MM patients treated upfront with lenalidomide who demonstrated reduced HSC mobilization with G-CSF alone. ${ }^{8,15-18}$ A steep dose-response curve exists for cyclophosphamide, with myelosuppression being the dose-limiting factor. ${ }^{19}$

Chemomobilization in combination with G-CSF is often disease specific and may eliminate the need for separate mobilization therapy following induction or salvage treatment. In lymphoma, salvage chemotherapy regimens such as IVE (ifosfamide, vincristine, etoposide), IEV (ifosfamide, epirubicin, etoposide), ICE (ifosfamide, carboplatin, etoposide) or DHAP (cytarabine, cisplatin, dexamethasone) are frequently used to both reduce tumor burden and enhance stem cell mobilization.

Patient responses to chemomobilization are variable. Unpredictable times to peak peripheral blood $\mathrm{CD}^{+}{ }^{+}$cells may result in delays to apheresis and inefficient use of healthcare resources. ${ }^{20}$ Chemomobilization is also associated with dose-dependent patient morbidity, greater risk of infection and febrile neutropenia, more hospital admissions and drug-specific toxicities, compared with G-CSF alone. ${ }^{21}$ In addition, chemotherapy may damage the bone marrow microenvironment and impair engraftment with possible long-term adverse effects and compromised future mobilization attempts. ${ }^{3,13}$ Thus, unless the antitumor activity is proven, chemotherapy to mobilize HSCs may not be cost-effective and may result in some risks for patients.

Plerixafor was developed in response to the unmet need for more effective mobilization agents. Plerixafor is a small bicyclam molecule that reversibly and selectively antagonizes the CXCR4 chemokine receptor and blocks binding of its cognate ligand, stromal cell-derived factor-1- $\alpha$ (SDF-1- $\alpha$ or CXCL12), resulting in mobilization of $\mathrm{CD}_{3}{ }^{+}$cells to the 
peripheral blood. Plerixafor is rapidly absorbed following subcutaneous injection reaching peak concentrations in $30-60 \mathrm{~min}$, and alone results in rapid increases in peripheral blood $\mathrm{CD}_{3}{ }^{+}$cells following a single injection in healthy donors. It exhibits linear kinetics over studied doses of $40-240 \mu \mathrm{g} / \mathrm{kg}$, is eliminated unchanged in urine and has a half-life of $3-5 \mathrm{~h}$ in patients with normal renal function. ${ }^{22,23}$ Plerixafor as a single agent has also been investigated in patients with $M M$, all of whom achieved enough cells for at least one transplant and demonstrated prompt recovery of hematopoietic function. ${ }^{24}$ When plerixafor is combined with G-CSF, HSC mobilization is enhanced compared with either plerixafor or G-CSF alone with peak $\mathrm{CD} 4^{+}$cell counts $10-14 \mathrm{~h}$ following administration. ${ }^{25}$ Plerixafor is generally safe and well tolerated both in healthy volunteers and in patients with NHL and $\mathrm{MM}^{23-27}$ Most adverse effects are described as mild and transient (Table 2). Severe adverse events are rare and include hypotension and dizziness after drug administration and thrombocytopenia after apheresis. ${ }^{28}$ In common with other HSC mobilization regimens, there is a potential risk of tumor cell mobilization and increased risk of metastases. The clinical significance of tumor cell mobilization is unclear, however, and may not affect long-term outcomes. ${ }^{29,30}$ Data indicate that tumor cell contamination is not evident, or not significantly increased, following plerixafor treatment, compared with G-CSF alone, in MM and $\mathrm{NHL}$ patients. ${ }^{31,32}$ However, increased circulating tumor cells have been reported in acute myelogenous leukemia and plasma cell leukemia patients. Therefore, plerixafor is not recommended for HSC mobilization in leukemia patients.

The mobilization efficacy of plerixafor was demonstrated in two phase III, multicenter, randomized, double-blind, placebocontrolled studies, which investigated primary HSC mobilization in patients with $\mathrm{NHL}$ and $M \mathrm{MM}^{28,33}$ The primary end point for the NHL trial was the collection of $\geqslant 5 \times 10^{6} \mathrm{CD} 34^{+}$cells $/ \mathrm{kg}$

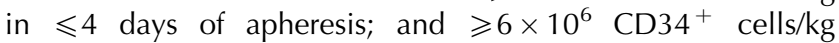
collected in $\leqslant 2$ days of apheresis for the MM trial. The treatment protocol for both patient groups was G-CSF $(10 \mu \mathrm{g} / \mathrm{kg} /$ day) + plerixafor $(240 \mu \mathrm{g} / \mathrm{kg})$ or G-CSF $(10 \mu \mathrm{g} / \mathrm{kg} /$ day $)+$ placebo. Placebo or plerixafor was administered on the evening of day 4 within a standard G-CSF mobilization regimen and apheresis was initiated on day 5 irrespective of peripheral blood CD34 ${ }^{+}$ cell count. Treatment was continued for up to four apheresis sessions or until the target number of $\mathrm{CD} 34^{+}$cells was collected (Figure 1). ${ }^{28,33}$

In the NHL group, 89 (59\%) of 150 patients in the plerixafor group and $29(20 \%)$ of 148 patients in the placebo group achieved the primary end point $(P<0.001)$. Of the plerixafor

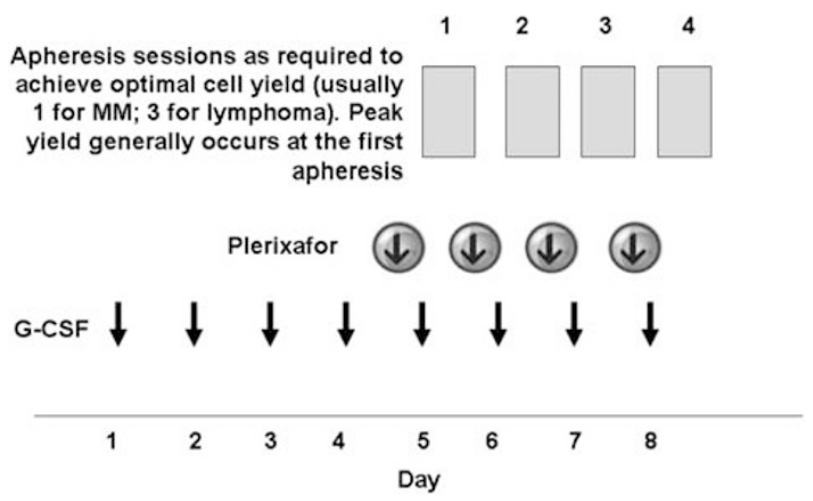

Figure 1 HSC mobilization and apheresis schedule for plerixafor in conjunction with G-CSF as described in phase III trials. ${ }^{46,47}$ group, 135 (90\%) underwent transplantation after initial mobilization compared with 82 patients $(55 \%)$ in the placebo group $(P<0.001)$. Median time to platelet and neutrophil engraftment was similar in both groups. In the MM group, 106 of $148(71.6 \%)$ patients in the plerixafor group and 53 of 154 $(34.4 \%)$ patients in the placebo group met the primary end point $(P<0.001)$. A total of $54 \%$ of plerixafor-treated patients reached the $\mathrm{CD}_{34}{ }^{+}$cell target after one apheresis, whereas $56 \%$ of the placebo-treated patients required four apheresis sessions.

Patients with NHL in either arm of the above phase III clinical trial who failed mobilization $\left(<0.8 \times 10^{6} \mathrm{CD}^{+} 4^{+}\right.$cells $/ \mathrm{kg}$ in two apheresis sessions or $<2 \times 10^{6} \mathrm{CD}^{2} 4^{+}$cells $/ \mathrm{kg}$ in four sessions) were eligible for a 'rescue' protocol. After a minimum 7 -day rest period, these patients received G-CSF $(10 \mu \mathrm{g} / \mathrm{kg} /$ day $)$ for 4 days, followed by daily plerixafor $(240 \mu \mathrm{g} / \mathrm{kg})$ plus G-CSF and apheresis for up to 4 days. Of the 68 patients failing initial mobilization (plerixafor, $n=11$; placebo, $n=57$ ), 62 patients $(91 \%)$ entered the rescue procedure $(n=10$ for plerixafor arm, $n=52$ for placebo arm). Four of 10 patients (40\%) from the plerixafor group and 33 of $52(63 \%)$ from the placebo group mobilized $\geqslant 2 \times 10^{6}$ cells $/ \mathrm{kg}$ from the rescue mobilization alone. $^{34}$

Plerixafor has also been made available to poor mobilizers through a compassionate use program. Results from a recent European compassionate use program study in 56 patients (32 with MM and 24 with lymphoma), who had collectively failed 73 previous mobilization attempts, showed a $75 \%$ successful collection rate $\left(\geqslant 2 \times 10^{6} \mathrm{CD} 34^{+}\right.$cells $\left./ \mathrm{kg}\right)$ in a median of two apheresis procedures when treated with plerixafor and G-CSF. A total of $71 \%$ of plerixafor-treated patients reached $\geqslant 10$ $\mathrm{CD} 4^{+}$cells/ $\mu$ l on day 5 (median 17.9 , range $2.8-192.2$ ) after a 7.6-fold expansion from day 4 . Of note, $84 \%$ of MM patients mobilized successfully, including those who had a previous auto-HSC transplantation or who had been treated with lenalidomide. ${ }^{35}$

Compassionate use program outcomes in patients who had previously failed to mobilize sufficient cells for transplant (that is, at least $2 \times 10^{6} \mathrm{CD} 34^{+}$cells $/ \mathrm{kg}$ ) achieved success rates of $60 \%$ for NHL $(n=63), 71 \%$ for MM $(n=35)$ and $76 \%$ for Hodgkin's lymphoma $(n=17)$ when treated with plerixafor and G-CSF. ${ }^{35}$ Other authors have reported similar success rates $(70-85 \%)$ in patients who had failed previous mobilization attempts. ${ }^{32,36,37}$

Patients who have been heavily pretreated with chemotherapy are at particular risk of mobilization failure. ${ }^{6,38}$ The effect of plerixafor on HSC mobilization in these patients was investigated in 28 patients with $\mathrm{NHL}$ or MM treated with more than nine cycles of chemotherapy, platinum-based therapy and/ or radiotherapy to bone marrow sites. The median increase in circulating $\mathrm{CD}^{+} 4^{+}$cells/ $\mu \mathrm{l}$ was 2.6 -fold after plerixafor and G-CSF therapy, enabling auto-HSC transplantation in all 28 patients. $^{39}$

Putting these findings in perspective, the aim of HSC mobilization is always to collect sufficient $\mathrm{CD} 34^{+}$cells for transplantation, preferably in the first mobilization attempt and ideally with a minimum of apheresis sessions. Each failure or delay to collect HSCs extends the time to high-dose chemotherapy and increases the risk of disease progression. The benefits and limitations of G-CSF alone and G-CSF in combination with chemotherapy as stem cell mobilizing agents are summarized in Table 1. On the basis of outcomes from clinical trials and US and European Union compassionate use program outcomes, plerixafor in combination with G-CSF provides a compelling alternative strategy (Table 2). Plerixafor alone may also have a role in circumstances in which G-CSF or 
Table 1 Summary of benefits and limitations of most widely used traditional HSC mobilization methods

\begin{tabular}{|c|c|c|}
\hline Method & Benefits & Limitations \\
\hline $\begin{array}{l}\text { Standard G-CSF } \\
\text { therapy alone }\end{array}$ & $\begin{array}{l}\text { Relatively low toxicity, common adverse events } \\
\text { include bone pain, headache, anemia and } \\
\text { decreased platelet counts } \\
\text { Predictable peak CD } 34^{+} \text {level ( } 4-5 \text { days); } \\
\text { reliable apheresis scheduling } \\
\text { Outpatient administration } \\
\text { Generally, high efficacy } \\
\text { Reduced costs compared with } \\
\text { G-CSF+chemotherapy }\end{array}$ & $\begin{array}{l}\text { Lower } \mathrm{CD} 34^{+} \text {cell yields compared with } \\
\text { G-CSF+chemotherapy } \\
\text { Variable failure rates }\end{array}$ \\
\hline G-CSF+chemotherapy & $\begin{array}{l}\text { Higher HSC yields compared with G-CSF alone } \\
\text { Anticancer activity } \\
\text { Fewer apheresis procedures }\end{array}$ & $\begin{array}{l}\text { Less predictable peak CD } 34^{+} \text {(10-18 days); less } \\
\text { efficient use of apheresis facilities } \\
\text { Greater toxicity compared with G-CSF alone } \\
\text { No improvement in failure rates compared with } \\
\text { G-CSF } \\
\text { May incur damage to bone marrow } \\
\text { microenvironment, impair engraftment and impair } \\
\text { future mobilizations } \\
\text { Need to hospitalize patients for } 1-3 \text { days for } \\
\text { administration of chemotherapy } \\
\text { Need for daily blood tests to monitor CD34 } \\
\text { mobilization } \\
\text { Higher costs compared with G-CSF alone } \\
\text { No benefit compared with G-CSF alone in the } \\
\text { second mobilization attempt }\end{array}$ \\
\hline
\end{tabular}

Abbreviations: G-CSF, granulocyte colony-stimulating factor; HSC, hematopoietic stem cell.

Table 2 Summary of benefits and limitations of plerixafor

\begin{tabular}{|c|c|c|}
\hline Method & Benefits & Limitations \\
\hline Plerixafor+G-CSF & $\begin{array}{l}\text { Predictable time to peak CD34 }{ }^{+} \text {cells ( } \sim 11 \mathrm{~h} \text { ): } \\
\text { reliable apheresis planning; more efficient use of } \\
\text { healthcare resources } \\
\text { Fewer mobilization failures compared with G-CSF } \\
\text { alone, reduced need for remobilization } \\
\text { More patients able to proceed to high-dose } \\
\text { chemotherapy } \\
\text { Faster time to high-dose chemotherapy } \\
\text { Reduced risk of disease progression } \\
\text { More cells per apheresis: higher cell doses for } \\
\text { auto-HSCT; possible option of collecting cells for } \\
\text { tandem/salvage transplant } \\
\text { Fewer apheresis sessions, fewer procedural side } \\
\text { effects } \\
\text { Fewer days of G-CSF } \\
\text { Adverse events: mild and transient (most commonly } \\
\text { diarrhea, nausea and injection site reactions) }\end{array}$ & $\begin{array}{l}\text { Currently indicated for failed or poor mobilizers in } \\
\text { Europe and not in general first-line treatment } \\
\text { Limited data on outcomes in association with } \\
\text { chemomobilization } \\
\text { Likely to be more expensive than current mobilization } \\
\text { options }\end{array}$ \\
\hline
\end{tabular}

Abbreviations: G-CSF, granulocyte colony-stimulating factor; HSCT, hematopoietic stem cell transplantation.

chemotherapy-based mobilization is not suitable, although HSC mobilization is modest compared with plerixafor and G-CSF in combination G-CSF. ${ }^{24}$

The current indication in Europe for plerixafor is in combination with G-CSF to enhance mobilization of HSCs to the peripheral blood for collection and subsequent autologous transplantation in patients with lymphoma and $\mathrm{MM}$, whose cells mobilize poorly'. This indication allows physicians to use plerixafor in the broad group of patients who are at risk of poor mobilization, as well as those who have previously failed conventional mobilization. The effectiveness of plerixafor in increasing HSC mobilization suggests an additional potential role in primary mobilization to reduce the risk of mobilization failure. This is especially appropriate in patients who, on monitoring of peripheral blood $\mathrm{CD}_{3}{ }^{+}$cell counts, do not mobilize HSCs at a rate consistent with achieving target yields or do not achieve sufficient numbers of circulating CD34 ${ }^{+}$cells to proceed to apheresis. Preemptive administration of plerixafor in these cases may 'rescue' the mobilization process and enable the patient to proceed promptly to high-dose chemotherapy without having to undergo an expensive and time-consuming repeat mobilization. Similarly, patients who are predicted to be poor mobilizers on the basis of age, treatment history and disease profile may also benefit potentially from plerixafor in first-line treatment to help avoid further mobilization attempts. $^{32,39}$

In cases in which chemotherapy with G-CSF is used only for mobilization purposes, plerixafor could be used to replace 
chemomobilization and avoid unnecessary exposure to the side effects of chemotherapy. Plerixafor with G-CSF, compared with cyclophosphamide with G-CSF, has demonstrated similar numbers of cells collected, similar costs of mobilization and similar clinical outcomes, ${ }^{40,41}$ although mobilization with plerixafor provides greater predictability for apheresis. ${ }^{41}$ Plerixafor in combination with chemomobilization has not been extensively studied, although a preliminary study in NHL and MM patients indicates that plerixafor may be added safely to chemotherapy with G-CSF-based mobilization regimens and may accelerate the rate of increase in $\mathrm{CD} 34^{+}$cells. $^{42}$

Following the introduction of plerixafor, the International Myeloma Working Group reviewed stem cell mobilization issues for transplantation in MM patients. It recommends studies to look at optimizing collection strategies after exposure to novel therapies (particularly lenalidomide-based combinations) with plerixafor and G-CSF or plerixafor plus chemotherapy. ${ }^{16,17}$ The ability to mobilize greater numbers of $\mathrm{CD} 34^{+}$cells may provide more opportunities to deliver optimal cell doses at transplant with faster engraftment and, potentially, better longterm outcomes. ${ }^{30,43,44}$ Increased CD34 ${ }^{+}$cell yield, in addition, may allow cells to be stored for tandem or salvage transplantation, avoiding the need to attempt mobilization at a time when mobilization could be challenging for the patient.

Although investigators usually focus on $\mathrm{CD} 4^{+}$yield as a major factor predicting transplant success, other factors such as the quality of the cell product composition, rate of engraftment and immune reconstitution may also contribute to long-term outcomes. A faster time to engraftment lowers the risk of potentially fatal infections and bleeding. This may be influenced not only by the total $\mathrm{CD} 34^{+}$cell dose but also by levels of $\mathrm{CD} 4^{+}$cell subsets, which influence neutrophil or platelet engraftment. ${ }^{45,46}$ It has been suggested that the more primitive HSCs mobilized by plerixafor in combination with G-CSF may have a greater capacity for reconstituting bone marrow compared with those mobilized by G-CSF alone. ${ }^{47}$

In conclusion, the availability of plerixafor is a significant advance, increasing the number of patients for whom auto-HSC transplantation is a potentially effective treatment option and increasing the number of patients able to proceed, in as short a time as possible, to high-dose chemotherapy. On the basis of currently available mobilization regimens, we expect plerixafor to become increasingly the mobilization method of choice for MM, NHL and Hodgkin's lymphoma patients likely to benefit from high-dose chemotherapy.

\section{Conflict of interest}

Dr Mohty has acted as a consultant to Genzyme and Amgen, the products of which are discussed in this manuscript. Drs Duarte, Russell and Hübel have also acted as consultants to Genzyme.

\section{Acknowledgements}

We thank Roberto M Lemoli, MD, Istituto di Ematologia e Oncologia, Medica 'L. e A. Seràgnoli', Bologna, Italy for taking part in discussions on stem cell mobilization strategies and for critical reading of the manuscript. This publication was supported by an unrestricted educational grant from Genzyme Corporation, Cambridge, MA. Medical writing support was provided by $\mathrm{P}$ Pickering, Conscience Creative LLP, Leatherhead, UK. The opinions or views expressed in this paper are those of the authors and do not necessarily reflect the opinions or recommendations of Genzyme Corporation.

M Mohty ${ }^{1,7}$, RF Duarte ${ }^{2,7}$, S Croockewit $^{3}$, K Hübel $^{4}$, $\mathrm{G}$ Kvalheim ${ }^{5}$ and $\mathrm{N}$ Russell ${ }^{6}$

${ }^{1}$ Centre Hospitalier et Universitaire (CHU) de Nantes, Hématologie Clinique, Centre d'Investigation Clinique en Cancérologie (CI2C), INSERM U892, Nantes, France, ${ }^{2}$ Institut Català d'Oncologia (ICO), Bone Marrow Transplant Programme \& Myeloid Leukemia Division, Hospital Duran i Reynals, L'Hospitalet de Llobregat, Barcelona, Spain;

${ }^{3}$ Hematology Department, Radboud University Nijmegen Medical Centre, Nijmegen, The Netherlands;

${ }^{4}$ Klinik I für Innere Medizin, Universitätsklinikum Köln, Köln, Germany;

${ }^{5}$ Radiumhospitalet, Oslo University Hospital, Oslo, Norway and

${ }^{6}$ Centre for Clinical Haematology, Nottingham University Hospital, Nottingham, UK E-mail: mohamad.mohty@univ-nantes.fr ${ }^{7}$ These authors contributed equally to this work.

\section{References}

1 Gratwohl A, Baldomero H, Schmid O, Horisberger B, Bargetzi M, Urbano-Ispizua A. Change in stem cell source for hematopoietic stem cell transplantation (HSCT) in Europe: a report of the EBMT activity survey 2003. Bone Marrow Transplant 2005; 36: 575-590.

2 Pavone V, Gaudio F, Console G, Vitolo U, lacopino P, Guarini A et al. Poor mobilization is an independent prognostic factor in patients with malignant lymphomas treated by peripheral blood stem cell transplantation. Bone Marrow Transplant 2006; 37: 719-724.

3 Bensinger W, DiPersio JF, McCarty JM. Improving stem cell mobilization strategies: future directions. Bone Marrow Transplant 2009; 43: 181-195.

4 Pusic I, Jiang SY, Landua S, Uy GL, Rettig MP, Cashen AF et al. Impact of mobilization and remobilization strategies on achieving sufficient stem cell yields for autologous transplantation. Biol Blood Marrow Transplant 2008; 14: 1045-1056.

5 Limat S, Woronoff-Lemsi MC, Milpied N, Chartrin I, Ifrah N, Deconinck $\mathrm{E}$, et al., Groupe Ouest Est d' é tude des Leuc é mies et Autres Maladies du Sang (GOELAMS). Effect of cell determinant (CD)34+ cell dose on the cost and consequences of peripheral blood stem cell transplantation for non-Hodgkin's lymphoma patients in front-line therapy. Eur J Cancer 2000; 36: 2360-2367.

6 Kuittinen T, Nousiainen T, Halonen P, Mahlamäki E, Jantunen E. Prediction of mobilisation failure in patients with non-Hodgkin's lymphoma. Bone Marrow Transplant 2004; 33: 907-912.

7 Akhtar S, Weshi AE, Rahal M, Khafaga Y, Tbakhi A, Humaidan H et al. Factors affecting autologous peripheral blood stem cell collection in patients with relapsed or refractory diffuse large cell lymphoma and Hodgkin lymphoma: a single institution result of 168 patients. Leuk Lymphoma 2008; 49: 769-778.

8 Popat U, Saliba R, Thandi R, Hosing C, Qazilbash M, Anderlini P et al. Impairment of filgrastim-induced stem cell mobilization after prior lenalidomide in patients with multiple myeloma. Biol Blood Marrow Transplant 2009; 15: 718-723.

9 Gabriel IH, Sharon J, Olavarria E, Rahemtulla A, Kanfer E, Marin D et al. Efficacy, complication rates, and cost effectiveness of chemotherapy plus granulocyte colony stimulating factor conditioned mobilisation of peripheral blood haematopoietic stem cells in over 150 patients with haematological malignancies. Blood (ASH Annu Meet Abstr) 2008; 112; abstract 2378. Available online: http://abstracts.hematologylibrary.org/content/vol112/issue11/.

10 Seggewiss R, Buss EC, Herrmann D, Goldschmidt H, Ho AD, Fruehauf $\mathrm{S}$. Kinetics of peripheral blood stem cell mobilization following G-CSF-supported chemotherapy. Stem Cells 2003; 21: 568-574.

11 Méndez-Ferrer S, Frenette PS. Hematopoietic stem cell trafficking: regulated adhesion and attraction to bone marrow microenvironment. Ann N Y Acad Sci 2007; 1116: 392-413. 
12 Tigue CC, McKoy JM, Evens AM, Trifilio SM, Tallman MS, Bennett CL. Granulocyte-colony stimulating factor administration to healthy individuals and persons with chronic neutropenia or cancer: an overview of safety considerations from the Research on Adverse Drug Events and Reports project. Bone Marrow Transplant 2007; 40: 185-192.

13 Gertz MA, Kumar SK, Lacy MQ, Dispenzieri A, Hayman SR, Buadi FK et al. Comparison of high-dose $\mathrm{CY}$ and growth factor with growth factor alone for mobilization of stem cells for transplantation in patients with multiple myeloma. Bone Marrow Transplant 2009; 43: 619-625.

14 Milone G, Leotta S, Indelicato F, Mercurio S, Moschetti G, Di Raimondo $\mathrm{F}$ et al. G-CSF alone vs cyclophosphamide plus G-CSF in PBPC mobilization of patients with lymphoma: results depend on degree of previous pretreatmen. Bone Marrow Transplant 2003; 31: 747-754.

15 Paripati H, Stewart AK, Cabou S, Dueck A, Zepeda VJ, Pirooz N et al. Compromised stem cell mobilization following induction therapy with lenalidomide in myeloma. Leukemia 2008; 22: 1282-1284.

16 Kumar S, Giralt S, Stadtmauer EA, Harousseau JL, Palumbo A, Bensinger $\mathrm{W}$ et al., International Myeloma Working Group. Mobilization in myeloma revisited: IMWG consensus perspectives on stem cell collection following initial therapy with thalidomidelenalidomide-, or bortezomib-containing regimens. Blood 2009; 114: 1729-1735.

17 Giralt S, Stadtmauer EA, Harousseau IL, Palumbo A, Bensinger W, Comenzo RL et al. IMWG International myeloma working group (IMWG) consensus statement and guidelines regarding the current status of stem cell collection and high-dose therapy for multiple myeloma and the role of plerixafor (AMD 3100). Leukemia 2009; 23: 1904-1912.

18 Mark T, Stern J, Furst JR, Jayabalan D, Zafar F, LaRow A et al. Stem cell mobilization with cyclophosphamide overcomes the suppressive effect of lenalidomide therapy on stem cell collection in multiple myeloma. Biol Blood Marrow Transplant 2008; 14: 795-798.

19 Moore MJ. Clinical pharmacokinetics of cyclophosphamide. Clin Pharmacokinet 1991; 20: 194-208 (review).

20 Hicks ML, Lonial S, Langston A, Flowers C, Roback JD, Smith KJ et al. Optimizing the timing of chemotherapy for mobilizing autologous blood hematopoietic progenitor cells. Transfusion 2007; 47: 629-635.

21 Jantunen E, Putkonen M, Nousiainen T, Pelliniemi TT, Mahlamäki E, Remes K. Low-dose or intermediate-dose cyclophosphamide plus granulocyte colony-stimulating factor for progenitor cell mobilisation in patients with multiple myeloma. Bone Marrow Transplant 2003; 31: 347-351.

22 Liles WC, Broxmeyer HE, Rodger E, Wood B, Hübel K, Cooper S et al. Mobilization of hematopoietic progenitor cells in healthy volunteers by AMD3100, a CXCR4 antagonist. Blood 2003; 102: $2728-2730$.

23 Hübel K, Liles WC, Broxmeyer HE, Rodger E, Wood B, Cooper S et al. Leukocytosis and mobilization of CD34+ hematopoietic progenitor cells by AMD3100, a CXCR4 antagonist. Support Cancer Ther 2004; 1: 165-172.

24 Flomenberg N, Comenzo RL, Badel K, Calandra G. Plerixafor (Mozobil(R)) alone to mobilize hematopoietic stem cells from multiple myeloma patients for autologous transplantation. Biol Blood Marrow Transplant 2010; 16: 695-700.

25 Liles WC, Rodger E, Broxmeyer HE, Dehner C, Badel K, Calandra $\mathrm{G}$ et al. Augmented mobilization and collection of CD34+ hematopoietic cells from normal human volunteers stimulated with granulocyte-colony-stimulating factor by single-dose administration of AMD3100, a CXCR4 antagonist. Transfusion 2005; 45: 295-300.

26 Cashen A, Lopez S, Gao F, Calandra G, MacFarland R, Badel K et al. A phase II study of plerixafor (AMD3100) plus G-CSF for autologous hematopoietic progenitor cell mobilization in patients with Hodgkin lymphoma. Biol Blood Marrow Transplant 2008; 14 1253-1261.

27 Stewart DA, Smith C, MacFarland R, Calandra G. Pharmacokinetics and pharmacodynamics of plerixafor in patients with nonHodgkin lymphoma and multiple myeloma. Biol Blood Marrow Transplant 2009; 15: 39-46.
28 DiPersio JF, Micallef IN, Stiff PJ, Bolwell BJ, Maziarz RT, Jacobsen E et al., 301 Investigators. Phase III prospective randomized double-blind placebo-controlled trial of plerixafor plus granulocyte colony-stimulating factor compared with placebo plus granulocyte colony-stimulating factor for autologous stem-cell mobilization and transplantation for patients with non-Hodgkin's lymphoma. J Clin Oncol 2009; 27: 4767-4773.

29 Bourhis JH, Bouko Y, Koscielny S, Bakkus M, Greinix H, Derigs G, et al., European Group for Blood and Marrow Transplantation. Relapse risk after autologous transplantation in patients with newly diagnosed myeloma is not related with infused tumor cell load and the outcome is not improved by CD34+ cell selection: long term follow-up of an EBMT phase III randomized study. Haematologica 2007: 92: 1083-1090.

30 Blystad AK, Delabie J, Kvaløy S, Holte H, Vålerhaugen H, Ikonomou I et al. Infused CD34 cell dose, but not tumour cell content of peripheral blood progenitor cell grafts, predicts clinical outcome in patients with diffuse large B-cell lymphoma and follicular lymphoma grade 3 treated with high-dose therapy. $\mathrm{Br} J$ Haematol 2004; 125: 605-612.

31 Fruehauf S, Ehninger G, Hübel K, Topaly J, Goldschmidt H, Ho AD et al. Mobilization of peripheral blood stem cells for autologous transplant in non-Hodgkin's lymphoma and multiple myeloma patients by plerixafor and G-CSF and detection of tumor cell mobilization by PCR in multiple myeloma patients. Bone Marrow Transplant 2010; 45: 269-275

32 Tricot G, Cottler-Fox MH, Calandra G. Safety and efficacy assessment of plerixafor in patients with multiple myeloma proven or predicted to be poor mobilizers, including assessment of tumor cell mobilization. Bone Marrow Transplant 2010; 45: 63-68.

33 DiPersio JF, Stadtmauer EA, Nademanee A, Micallef IN, Stiff PJ, Kaufman JL, et al., 3102 Investigators. Plerixafor and G-CSF versus placebo and G-CSF to mobilize hematopoietic stem cells for autologous stem cell transplantation in patients with multiple myeloma. Blood 2009; 113: 5720-5726.

34 Micallef IN, Stiff PJ, DiPersio JF, Maziarz RT, McCarty JM, Bridger $G$ et al. Successful stem cell remobilization using plerixafor (mozobil) plus granulocyte colony-stimulating factor in patients with non-hodgkin lymphoma: results from the plerixafor NHL phase 3 study rescue protocol. Biol Blood Marrow Transplant 2009; 15: 1578-1586.

35 Duarte RF, Shaw BE, Marín P, Kottaridis P, Ortiz M, Morante C et al. Plerixafor plus granulocyte CSF can mobilize hematopoietic stem cells from multiple myeloma and lymphoma patients failing previous mobilization attempts: EU compassionate use data. Bone Marrow Transplant 2010, e-pub ahead of print.

36 Calandra G, McCarty J, McGuirk J, Tricot G, Crocker SA, Badel K et al. AMD3100 plus G-CSF can successfully mobilize CD34+ cells from non-Hodgkin's lymphoma, Hodgkin's disease and multiple myeloma patients previously failing mobilization with chemotherapy and/or cytokine treatment: compassionate use data. Bone Marrow Transplant 2008; 41: 331-338.

37 Fowler CJ, Dunn A, Hayes-Lattin B, Hansen K, Hansen L, Lanier K et al. Rescue from failed growth factor and/or chemotherapy HSC mobilization with G-CSF and plerixafor (AMD3100): an institutional experience. Bone Marrow Transplant 2009; 43: 909-917.

38 Perea G, Sureda A, Martino R, Altés A, Martínez C, Cabezudo E et al. Predictive factors for a successful mobilization of peripheral blood CD34+ cells in multiple myeloma. Ann Hematol 2001; 80: 592-597.

39 Stiff $\mathrm{P}$, Micallef I, McCarthy P, Magalhaes-Silverman M, Weisdorf $D$, Territo $M$ et al. Treatment with plerixafor in non-Hodgkin's lymphoma and multiple myeloma patients to increase the number of peripheral blood stem cells when given a mobilizing regimen of G-CSF: implications for the heavily pretreated patient. Biol Blood Marrow Transplant 2009; 15: 249-256.

40 Nazha A, Cook R, Vogl DT, Mangan PA, Hummel K, Cunningham $\mathrm{K}$ et al. Plerixafor and G-CSF Versus Cyclophosphamide and G-CSF for Stem Cell Mobilization in Patients with Multiple Myeloma. Blood (ASH Annu Meet Abstr) 2009; 114; abstract 2146. Available online: http://abstracts.hematologylibrary.org/content/vol114/issue22/.

41 Shaughnessy P, Islas-Ohlmayer M, Murphy J, Hougham M MacPherson J, Winkler $\mathrm{K}$ et al. Plerixafor plus G-CSF compared to chemotherapy plus G-CSF for mobilization of autologous CD34+ Cells resulted in similar cost but more predictable days 
of apheresis and less hospitalization. Blood (ASH Annu Meet Abstr) 2009; 114; abstract 2277. Available online: http://abstracts. hematologylibrary.org/content/vol114/issue22/.

42 Dugan MJ, Maziarz RT, Bensinger WI, Nademanee A, Liesveld J, Badel $\mathrm{K}$ et al. Safety and preliminary efficacy of plerixafor (Mozobil) in combination with chemotherapy and G-CSF: an open-label, multicenter, exploratory trial in patients with multiple myeloma and non-Hodgkin's lymphoma undergoing stem cell mobilization. Bone Marrow Transplant 2010; 45: 39-47.

43 O'Shea D, Giles C, Terpos E, Perz J, Politou M, Sana V et al. Predictive factors for survival in myeloma patients who undergo autologous stem cell transplantation: a single-centre experience in 211 patients. Bone Marrow Transplant 2006; 37: 731-737.

44 Bolwell BJ, Pohlman B, Rybicki L, Sobecks R, Dean R, Curtis J et al. Patients mobilizing large numbers of CD34+ cells ('super mobilizers') have improved survival in autologous stem cell transplantation for lymphoid malignancies. Bone Marrow Transplant 2007; 40: 437-441.

45 Kamel AM, El-Sharkawy N, Mahmoud HK, Khalaf MR, El Haddad A, Fahmy O et al. Impact of CD34 subsets on engraftment kinetics in allogeneic peripheral blood stem cell transplantation. Bone Marrow Transplant 2005; 35: 129-136.

46 Wallington-Beddoe CT, Gottlieb DJ, Garvin F, Antonenas V, Sartor MM. Failure to achieve a threshold dose of CD34+CD110+ progenitor cells in the graft predicts delayed platelet engraftment after autologous stem cell transplantation for multiple myeloma. Biol Blood Marrow Transplant 2009; 15: 1386-1393.

47 Fruehauf S, Veldwijk MR, Seeger T, Schubert M, Laufs S, Topaly J et al. A combination of granulocyte-colony-stimulating factor (G-CSF) and plerixafor AMD3100 (plerixafor) mobilizes more primitive peripheral blood progenitor cells than G-CSF alone: results of a European phase II study. Cytotherapy 2009; 11: 992-1001. 